\title{
Thermal Time Utilization of Plum in Semi Arid Region of Gangetic Plain
}

\author{
Mohan Singh, Ram Niwas \\ Department of Agricultural Meteorology, Chaudhary Charan Singh Haryana Agricultural University, Haryana, India
}

Email address:

jangra_ms@live.com (M. Singh)

To cite this article:

Mohan Singh, Ram Niwas. Thermal Time Utilization of Plum in Semi Arid Region of Gangetic Plain. Science Research. Vol. 3, No. 1, 2015, pp. 19-24. doi: 10.11648/j.sr.20150301.14

\begin{abstract}
Plum prefers temperate climate thus a major crop of hills however, it has been found growing from higher hills in Srinagar to Jaipur in Rajasthan and areas around Delhi. It requires less chilling hours and can tolerate frost and high summers both, that is why it can be cultivated in both low temperatures to $0^{\circ} \mathrm{C}$ and up, highest up to $47^{\circ} \mathrm{C}$ in summers. Among the major Japanese cultivar the Kala Amritsari, Satluj Purple and Titron are planted at HAU farm in 2001 on which the present study was done during 2013-14. The overall growth was observed better in Kala Amritsari followed by Satluj purple and Titron which is a late maturing variety. The thermal time required by Kala Amritsari and Satluj Purple was at par but the Titron required more thermal indices. The heat use efficiency was observed highest for Kala Amritsari and lowest for Titron whereas the photothermal index was highest in Titron followed by Kala Amritsari and Satluj Purple. The thermal units explained the 94 per cent variation in fruit yield of Kala Amritsari, 87 per cent variation in Satluj Purple and 83 percent variation in fruit yield of Titron cultivar.
\end{abstract}

Keywords: Plum, Phenophases, GDD, HTU, PTU, HYTU, HUE

\section{Introduction}

Plum is native to China, although it became a commercial fruit of Japan and America. It is known as Japanese plum (Prunus salicina Lindell) due to its cultivation in Japan from where cultivars spread to other places. At present, plum is cultivated in all temperate climate countries of the world. It has been found growing from higher hills in Srinagar to Jaipur in Rajasthan and areas around Delhi in semi arid region of Gangetic plain of India. It requires less chilling hours and can tolerate frost and high summers both, that is why it can be cultivated in both low temperatures to $0^{\circ} \mathrm{C}$ and up, highest up to $47^{\circ} \mathrm{C}$ in summers. It may also be planted as a filler fruit plant in orchards due to low chilling requirement and less juvenile period. Plums are highly productive due to profuse flowering, high fruit set and early ripening habit of cultivars recommended for plains. The major cultivars of plum grown in plain area of Haryana and Punjab state are Kala Amritsari which is a self-fruitful high yielding local cultivar and is most preferred cultivar of plains. Its fruits are of medium size, round oblate depressed at both ends which ripen in second half of May. The cultivar Satluj Purple is a self-unfruitful cultivar and requires pollinizer for good fruit set. Tree is medium in vigor with upright habit of growth. It is an early ripening low yielding cultivar. Titron is a selffruitful cultivar but its yield increases if Alucha Early Round is used as a pollinizer. Titron trees are smaller than Kala Amritsari.

The plum tree remains in dormancy during December and January and bud beak takes place from first week of February after completing the chilling requirements under Haryana conditions. Prevailing weather conditions during the whole crop growing season have direct bearing upon the phenological events of the crop which ultimately affect the crop yield. The duration of each growth phase is a result of crop response to external environmental factors. Temperature is one of the important elements of the climate which determines directly the potential productivity level. Thermal time effect has been described as the independent variable to delineate plant growth and development (Dwyer and Stewart, 1986). Temperature based agrometeorological indices like GDD, HTU, PTU and HYTU are based on the concept that real time to attain the phenological stages is linearly related to temperature in the range between base temperature and the optimum temperature (Monteith, 1981). This concept is widely used for growth, phenological development and yield of different crops (Rajput et al., 1987; Shanker et al., 1996; 
Swan et al., 1989). Such works have been done elsewhere (Rao et al., 1999) it has not hitherto been reported from semi arid region of Haryana especially on fruit crops. Hence, the present investigation was carried out to assess the response of phenology and fruit yield of plum cultivars growing degree days and heat unit utilization under semi arid conditions.

\section{Materials and Methods}

Field experiment was conducted during 2013 and 2014 at experimental orchard of the Chaudhary Charan Singh Haryana Agricultural University Hisar $\left(29.10^{\circ} \mathrm{N}, 75.46^{\circ} \mathrm{E}\right.$ and $215 \mathrm{~m}$ amsl) to assess the heat unit utilization for different phenophases 13 years old three genotypes of plum planted at spacing of $6 \times 6$ meters. The spacing under reference accommodate 277 plants/ha. Pomologists have given different names to the various developmental growth stages of plum fruits tree. Out of these we have observed only six important phenophases of plum (Plate 1) which were recorded on marked four branches of five trees of each genotype by visiting the selected tree at two days interval. The meteorological data was collected from the Agromet Observatory situated in the research farm (Fig 1). Following agrometeorological indices and heat use efficiencies were calculated on daily basis and accumulated from bud burst to maturity/harvesting taking $10^{\circ} \mathrm{C}$ as base temperature. The dormant period was supposed to be over when the accumulated chilling hours started decreasing.

1. Growing degree days $(\mathrm{GDD})=(\mathrm{T} \max +\mathrm{Tmin}) / 2-10^{\circ} \mathrm{C}$

2. Photothermal unit $(\mathrm{PTU})=\mathrm{GDD} *$ Day Length

3. Heliothermal unit ( HTU $)=$ GDD * Sunshine Hours

4. Hydrothermal unit (HYTU) $=\mathrm{GDD} * \mathrm{RH}$

Under the semi arid conditions on an average accumulation of heat units started from January 22 in 2013 and from January 20 in 2014 when the accumulation of chilling hours started decreasing. The energy use efficiencies were computed ( $\left(\mathrm{kg} \mathrm{ha}^{-1}\right.$ per degree) to compare the relative performance of different cultivars with respect to utilization of heat unit using the following formulae:

1. Heat use efficiency $($ HUE $)=$ Fruit yield $\left(\mathrm{kg} \mathrm{ha}^{-1}\right) / \mathrm{GDD}^{\circ}$ C day.

2. Photothermal use efficiency $($ PTUE $)=$ Fruit yield $(\mathrm{kg}$ $\left.\mathrm{ha}^{-1}\right) / \mathrm{PTU}^{\circ} \mathrm{C}$ day.

3. Heliothermal use efficiency (HTUE) $=$ Fruit yield $\left(\mathrm{kgha}^{-1}\right) / \mathrm{HTU}^{\mathrm{o}} \mathrm{C}$ day.

4. Hydrothermal use efficiency $($ HYTUE $)=$ Fruit yield $(\mathrm{kg}$ $\left.\mathrm{ha}^{-1}\right) / \mathrm{HYTU}^{\mathrm{o}} \mathrm{C}$ day

Phenothermal index (PTI) for each phenophases was calculated as per following formula (Sastry and Chakravarty, 1982). PTI $=($ GDD $) /$ No. of days taken between two phenophases. Predictive regression relation models were also worked out between thermal indices and yield of different genotypes.

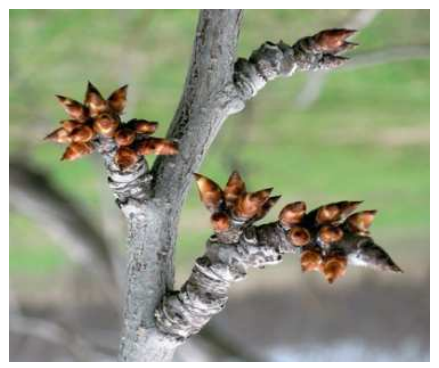

Dormant

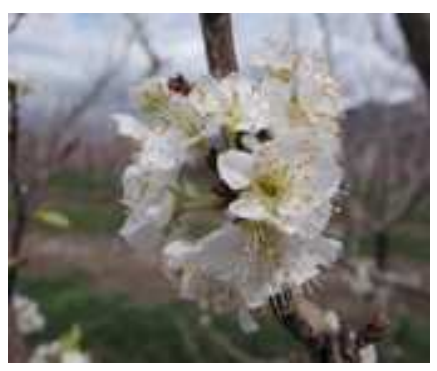

Full bloom

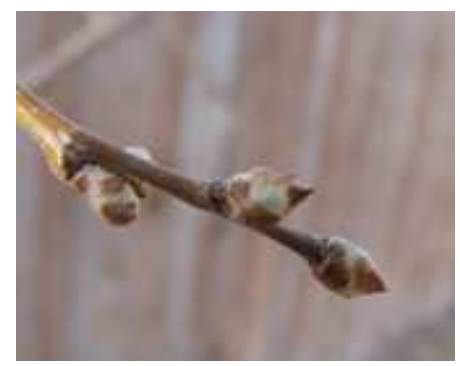

Bud burst

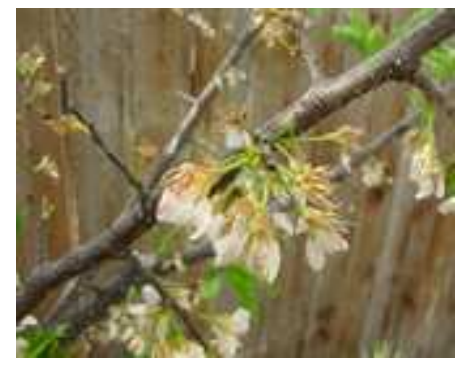

Petal fall

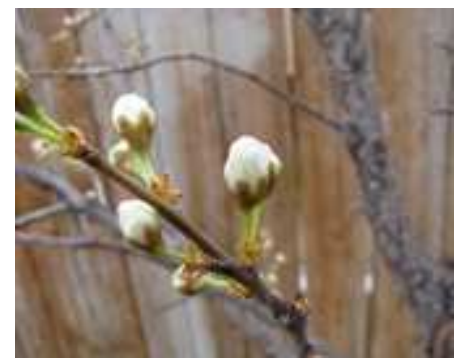

White bud

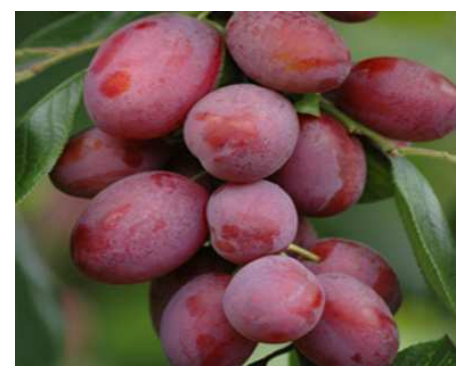

Maturity

Plate 1. Important phenophases recorded in Plum at Hisar. 


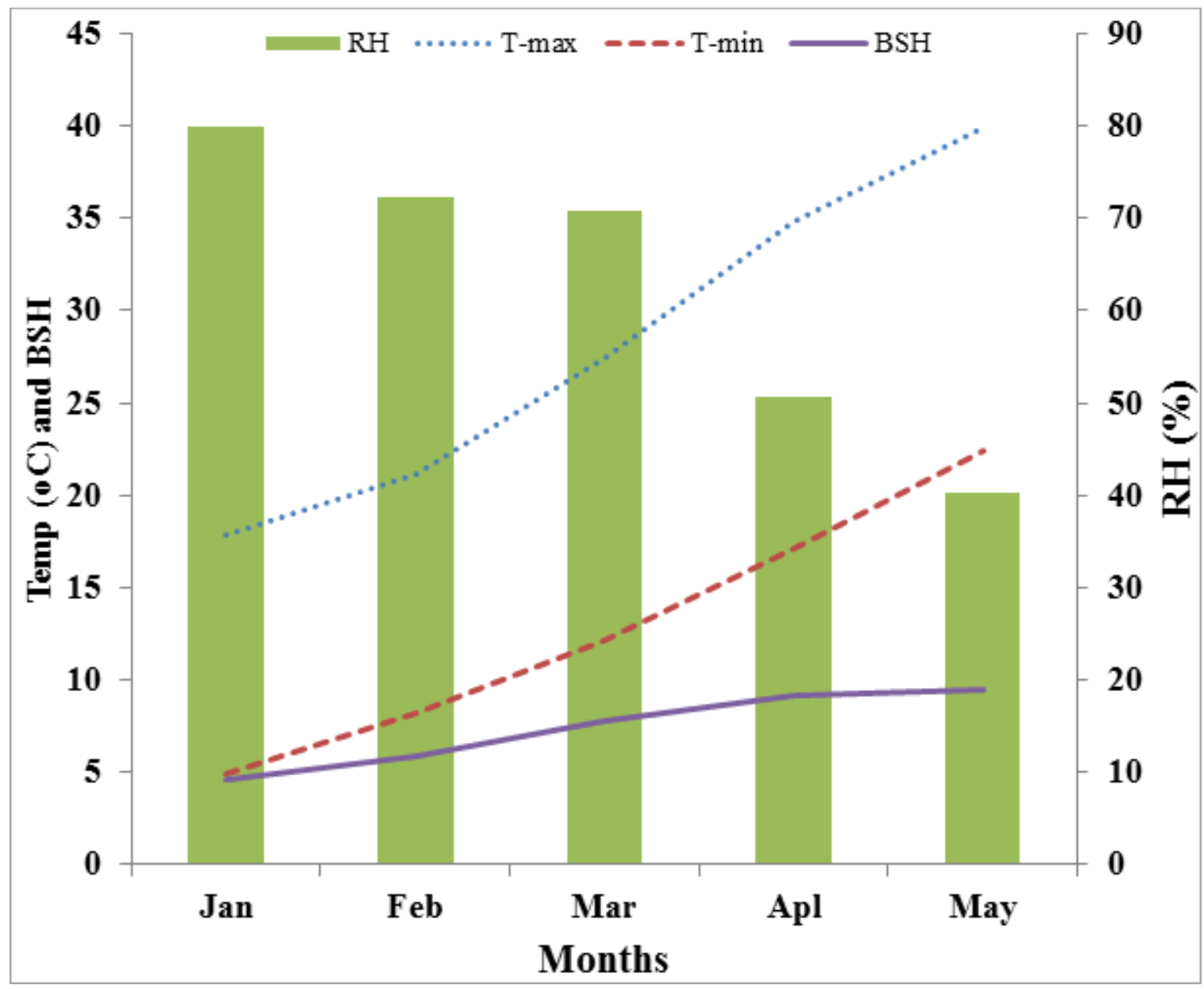

Fig. 1. Weather during the crop growth period (average of two years).

BHS: Bright sun shine hours

RH: Relative humidity

T-max: Maximum Temperature

T-min: Minimum temperature

\section{Results and Discussion}

\subsection{Thermal Indices}

Bud burst of all the three cultivars took place on first February during 2013 and on January 30 during 2014. Days taken to complete growth stages from dormant to bud burst, from bud burst to white-bud and from white-bud to fullbloom were lowest in Kala Amritsari followed by Satluj Purple and Titron. Similar trend was observed in photothermal units (PTU), heliothermal units (HTU) and hydrothermal unit (HYTU).

Kala Amritsari required absolute value of 35 GDD, 186 PTU, 375 HTU and 2876 HYTU to attain bud burst after completion of dormancy (Table 1); 35 GDD, 155 PTU, 380 HTU and 2857 HYTU from bud burst to attain white bud; 48 GDD, 284 PTU, 534 PTU and 3837 HYTU from white bud to full bloom; 41 GDD, 266 PTU, $470 \mathrm{HTU}$ and $3438 \mathrm{HYTU}$ from full bloom to petal fall and 805 GDD, 6971 PTU, 10144 HTU \& 45487 HYTU Table 2). Satluj Purple required 48 GDD, 234 PTU, 519 HTU and 3953 HYTU to attain bud burst after completion of dormancy; 35 GDD, 190 PTU, 386 HTU and 2910 HYTU from bud burst to white bud; 46 GDD, 279 PTU, 512 PTU and 3613 HYTU from white bud to full bloom; 41 GDD, 283 PTU, 463 HTU and 3262 HYTU from full bloom to petal fall and 816 GDD, 7065 PTU, 10292 HTU \& 45839 HYTU from petal fall to attain the maturity stage. The Titron which is a late maturing cultivar of plum required 56 GDD, 268 PTU, $606 \mathrm{HTU}$ and $4645 \mathrm{HYTU}$ to attain bud burst after completion of dormancy; 37 GDD, 225 PTU, 412 HTU and 3010 HYTU from bud burst to white bud; 50 GDD, 279 PTU, 564 PTU and 4082 HYTU from white bud to full bloom; 45 GDD, 363 PTU, 513 HTU and 3345 HYTU from full bloom to petal fall and 957 GDD, 8433 PTU, 12234 HTU \& 50793 HYTU from petal fall to maturity (Table 1).

The mean of two years of thermal indices by Kala Amritsari from break of dormancy to attain physiological maturity were 965 GDD, 7863 PTU, 11904 HTU and 58897 HYTU by Satluj purple 986 GDD, 8051 PTU, 12172 HTU and 59578 HYTU and by Titron 1146 GDD, 9570 PTU, 14332 HTU and 65876 HYTU (Table 2). The growth period 
during 2014 was almost one week longer as compared to 2013 which might be due to the cloud weather and more rains received from fruit set to maturity during 2014. Days taken to attain different phenophases by Kala Amritsari and
Satluj purple were almost at par but Titron has taken 3- 12 days more for attaining different growth stages in plum (Table 3).

Table 1. Thermal units used for attaining different Phenophases of different genotypes of plum.

\begin{tabular}{|c|c|c|c|c|}
\hline Gynotypes & GDD & PTU & HTU & HYTU \\
\hline \multicolumn{5}{|c|}{ Kala Amritsari } \\
\hline Bud burst & 35.2 & 186.0 & 375.0 & 2876.1 \\
\hline White bud & 35.0 & 155.3 & 380.1 & 2857.3 \\
\hline Fruit set & 41.3 & 266.3 & 470.3 & 3438.5 \\
\hline Maturity & 805.7 & 6971.9 & 10144.7 & 45887.8 \\
\hline \multicolumn{5}{|c|}{ Satluj Purple } \\
\hline White bud & 35.4 & 190.3 & 385.5 & 2910.7 \\
\hline Full bloom & 45.8 & 278.8 & 511.8 & 3612.5 \\
\hline Fruit set & 40.5 & 283.0 & 462.8 & 3262.2 \\
\hline Maturity & 815.8 & 7065.0 & 10292.9 & 45839.2 \\
\hline \multicolumn{5}{|l|}{ Titron } \\
\hline Bud burst & 56.6 & 268.3 & 606.6 & 4645.5 \\
\hline White bud & 37.6 & 225.7 & 412.6 & 3010.1 \\
\hline Full bloom & 50.1 & 279.6 & 564.5 & 4082.3 \\
\hline Maturity & 957.0 & 8433.2 & 12234.9 & 50793.3 \\
\hline
\end{tabular}

Table 2. Agrometeorological indices (degree days) to attain different phenophases in plum genoypes.

\begin{tabular}{|c|c|c|c|c|c|c|c|c|c|c|c|c|}
\hline \multirow[b]{2}{*}{ Kala Amritsari } & \multicolumn{4}{|l|}{2013} & \multicolumn{4}{|l|}{2014} & \multicolumn{4}{|l|}{ Mean } \\
\hline & GDD & PTU & HTU & HYTU & GDD & PTU & HTU & HYTU & GDD & PTU & HTU & HYTU \\
\hline Bud burst & 26.4 & 172.3 & 282.7 & 1909.5 & 43.9 & 199.8 & 467.3 & 3842.7 & 35.2 & 186.0 & 375.0 & 2876.1 \\
\hline White bud & 62.4 & 317.3 & 673.7 & 4733.0 & 78.0 & 365.3 & 836.5 & 6733.7 & 70.2 & 341.3 & 755.1 & 5733.4 \\
\hline Full bloom & 88.8 & 489.6 & 956.4 & 6642.5 & 121.9 & 565.1 & 1303.7 & 10576.4 & 105.3 & 527.3 & 1130.1 & 8609.5 \\
\hline Fruit set & 152.7 & 845.7 & 1687.6 & 11965.1 & 166.4 & 936.8 & 1831.6 & 14053.9 & 159.6 & 891.2 & 1759.6 & 13009.5 \\
\hline Maturity & 965.8 & 7797.7 & 11886.9 & 57446.5 & 964.8 & 7928.6 & 11921.6 & 60348.1 & 965.3 & 7863.2 & 11904.3 & 58897.3 \\
\hline Bud burst & 39.6 & 234.6 & 425.5 & 2871.1 & 57.5 & 234.1 & 613.4 & 5035.6 & 48.5 & 234.3 & 519.4 & 3953.4 \\
\hline White bud & 75.2 & 423.9 & 813.4 & 5680.4 & 92.6 & 425.3 & 996.4 & 8047.7 & 83.9 & 424.6 & 904.9 & 6864.1 \\
\hline Full bloom & 128.1 & 702.4 & 1404.4 & 9944.9 & 131.2 & 704.3 & 1428.9 & 11008.3 & 129.6 & 703.4 & 1416.6 & 10476.6 \\
\hline Fruit set & 173.9 & 1036.1 & 1927.3 & 13423.7 & 166.4 & 936.8 & 1831.6 & 14053.9 & 170.2 & 986.4 & 1879.5 & 13738.8 \\
\hline Maturity & 1007.1 & 8174.2 & 12423.1 & 58807.9 & 964.8 & 7928.6 & 11921.6 & 60348.1 & 985.9 & 8051.4 & 12172.3 & 59578.0 \\
\hline \multicolumn{13}{|l|}{ Titron } \\
\hline Bud burst & 48.4 & 261.8 & 521.0 & 3649.9 & 64.7 & 274.7 & 692.1 & 5641.0 & 56.6 & 268.3 & 606.6 & 4645.5 \\
\hline Fruit set & 192.0 & 1233.5 & 2141.9 & 14563.3 & 185.4 & 1040.6 & 2051.5 & 15602.3 & 188.7 & 1137.0 & 2096.7 & 15082.8 \\
\hline Maturity & 1164.0 & 9741.8 & 14552.0 & 63579.6 & 1127.4 & 9398.6 & 14111.2 & 68172.6 & 1145.7 & 9570.2 & 14331.6 & 65876.1 \\
\hline
\end{tabular}

Table 3. Days taken to attain different phenophases of plum genotypes.

\begin{tabular}{|c|c|c|c|c|c|c|}
\hline \multirow{2}{*}{ Phenophases } & \multicolumn{2}{|c|}{ Kala Amritsari } & \multicolumn{2}{|c|}{ Satluj Purple } & \multicolumn{2}{|c|}{ Titron } \\
\hline & 2013 & 2014 & 2013 & 2014 & 2013 & 2014 \\
\hline Bud burst & 11 & 11 & 13 & 15 & 14 & 16 \\
\hline Pink bud & 17 & 18 & 21 & 22 & 24 & 26 \\
\hline Full bloom & 29 & 32 & 32 & 33 & 34 & 36 \\
\hline Petal fall & 36 & 40 & 39 & 40 & 42 & 44 \\
\hline Maturity & 98 & 104 & 104 & 110 & 110 & 117 \\
\hline
\end{tabular}

\subsection{Phenothermal Index (PTI)}

Phenothermal index steadily increased from bud burst stage to maturity in all the cultivars. It was highest from petal fall to maturity stage which is the longest stage and during this period (March - April) the accumulation of heat units were higher. The value of the PTI was lowest in Satluj Purple followed by Kala Amritsari and Titron for different phenophases. On an average the PTI was 2.9, 3.9, 4.0, 4.3, and 9.2 for bud burst, white bud, full bloom, petal fall and physiological maturity, respectively in Satluj Purple. The corresponding values of PTI for Kala Amritsari were 3.2, 4.0, 
3.9, 4.2, and 9.6, and for Titron it were 3.8, 3.8, 4.1, 4.4 and 10.1 for bud burst, white bud, full bloom, petal fall and physiological maturity, respectively (Table 4).

Table 4. Photothermal index (PTI) during various phenological stages of plum genotypes.

\begin{tabular}{llllll}
\hline Cultivar & Bud burst & White bud & Full Bloom & Petal fall & Maturity \\
\hline Kala Amritsari & 3.2 & 4.0 & 3.9 & 4.2 & 9.6 \\
Satluj Purple & 2.9 & 3.9 & 4.0 & 4.3 \\
Titron & 3.8 & 3.8 & 4.1 & 9.2 & 4.4 \\
\hline
\end{tabular}

\subsection{Thermal Use Efficiency}

The efficiency of thermal, Heliothermal, photothermal and hydrothermal energy conversion for yield and dry matter depend upon genetic factors of crop and time of breaking of bud, after, the completion of the rest period. Thermal use efficiency was highest for the cultivar which required lower amount of thermal units for producing higher grain and biological yields. In plum the highest use efficiency $(21.5 \mathrm{~kg}$ $\mathrm{ha}^{-1} /$ GDD day) was observed in cultivar of Kala Amritsari followed by Satluj Purple (18.3 $\mathrm{kg} \mathrm{ha}^{-1} / \mathrm{GDD}$ day) and the lowest heat use efficiency (13.7 $\mathrm{kg} \mathrm{ha}^{-1} / \mathrm{GDD}$ day) was observed in Titron (Table 5). The utilization efficiency for other indices also followed similar trend. On an average the thermal use efficiency in Kala Amritsari was $12.4 \mathrm{~kg} \mathrm{ha}^{-}$ ${ }^{1}$ GDD day with 28 per cent of coefficient of variation. In Satluj purple it was $10.7 \mathrm{~kg} \mathrm{ha}^{-1} / \mathrm{GDD}$ day with 33 per cent of coefficient of variation and in Titron the average heat unit use efficiency was observed $8.7 \mathrm{~kg} \mathrm{ha}^{-1} / \mathrm{GDD}$ day per cent with 37 per cent of coefficient of variation. Similar trend was observed for other three thermal use efficiencies in both the cultivars.

Table 5. Thermal use efficiencies of three genotypes of plum at Hisar conditions.

\begin{tabular}{|c|c|c|c|c|}
\hline Cultivars & HUE kg ha hegree day $^{-1}$ & HTUE kg ha ${ }^{-1} /$ degree day & PTUE kg ha ${ }^{-1} /$ degree day & HYTUE kg ha" / degree day \\
\hline Kala Amritsari & 21.5 & 2.6 & 1.7 & 0.4 \\
\hline Satluj Purple & 18.3 & 2.2 & 1.5 & 0.3 \\
\hline Titron & 13.7 & 1.6 & 1.1 & 0.2 \\
\hline
\end{tabular}

\subsection{Predictive Model}

Regression models were developed for fruit yield prediction using thermal units consumed during this period. Strong and linear regression relationship was observed between fruit yield (FY) and Heat Units (HU). This prediction model holds good for all the other three thermal units (PTU, HTU and HYTU). The required equation for forecast of fruit yield is as under:

(1) For Kala Amritsari:

$$
\mathrm{FY}=4341 \mathrm{HU}-203.6\left(\mathrm{R}^{2}=0.94\right)
$$

(2) For Satluj Purple:

$$
\mathrm{FY}=0.3122 \mathrm{HU}-152.8\left(\mathrm{R}^{2}=0.88\right)
$$

(3) For Titron:

$$
\mathrm{FY}=4833 \mathrm{HU}-420.6\left(\mathrm{R}^{2}=0.84\right)
$$

(4) For Pooled data:

$$
\mathrm{FY}=-0.186 \mathrm{HU}+377.7\left(\mathrm{R}^{2}=0.71\right)
$$

The Kala Amritsari and Satluj purple showed higher thermal use efficiencies and also showed a better relation in comparison with Titron and the pooled model.

Thermal indices explained 94 percent variation in fruit yield of Kala Amritsari, 87 per cent variation in Satluj purple and 83 percent variation in Titron. Similar works on developing agroclimatic models based on temperature, photoperiod and day length for mustard (Hundal et al., 2003) for wheat (Hundal et al., 1970) have been reported under Punjab conditions and for apple fruit (Mohan Singh and H.S Bhatia, 2011) under mid hill region of Himachal Pradesh.

\section{Conclusions}

The thermal indices were calculated for three important cultivars of plum taking $10^{\circ} \mathrm{C}$ as base temperature. The plum cultivar Kala Amritsari required 70 GDD, Satluj purple 84 GDD and Titron 94 GDD to attain the first important phenophases (white bud) after bud break. Thermal indices explained more than 71 to 94 per cent variation in fruit yield of plum. In term of plant growth, plant girth, annual extension, fruit set and other physical parameters the performance of Kala Amritsari was observed better followed by Satluj Purple. Both these cultivar were observed precocious and fruiting was recorded in the third year after plantation. They are showing better utilization of heat units and hence, suitable for diversification in plum cultivation under changing and prevailing climatic conditions of Gigantic plain in general and semi arid region of Haryana in particular.

\section{References}

[1] Dwyer, L.M. and Steward, D.W. (1986). Leaf area development in field grown maize. Agron. J., 78: 334-348.

[2] Hundal, S.S., Prabhjyot-Kaur and Malikpuri, S.D.S. (2003). Agroclimatic models for prediction of growth and yield of Indian Mustard. Indian J. Agric. Sci., 73 (3): 142-144. 
[3] Hundal S.S., Singh, R. and Dhaliwal, L.K. (1997). Agroclimatic indices for predicting phenology of wheat in Punjab. Indian J. Agric. Sci., 67 (6):265-268.

[4] Mohan Singh and HS Bhatia (2011). Thermal time requirement for phenophases of apple genotypes in Kullu valley. J. Agrometeorol 13(1):46-49.

[5] Monteith J.L. (1981). Climate variation and growth of crops. Quart J. Royal Meteorol Soc. 107: 602-607.

[6] Rajput, R.P., Deshmukh, M.R and Paradker, V.K. (1987). Accumulated heat units and phenology relationship in wheat as influenced by planting dates under late sown conditions. $J$. Agron. Crop Sci, 159: 345-349.
[7] Rao, V.U.M., Singh, D. and Singh, R. (1999). Heat use efficiency of winter crops in Haryana. J. Agromet. 1:143-148.

[8] Sastry, P.S.N. and Chakravarty, N.V.K. (1982). Energy summation indices for wheat crop in India. Agric. Meteorol. 27: $45-48$

[9] Shanker, U., Agrawal, K.K. and Gupta, V.K. (1996). Heat unit requirement of rainfed soybean. Indian J. Agric. Sci. 66: 401404.

[10] Swan, J.B., Schneider, E.C., Moncrief, J.E., Paulson, W.H. and Peterson, A.E. (1989). Estimating crop growth yields and grain moisture from air growing degree days and residue cover. Agron. J., 79: 53-60. 